\title{
Ferrocyanide Safety Project \\ Task 3 Ferrocyanide Aging Studies FY 1993 Annual Report
}

\author{
M. A. Lilga \\ M. R. Lumetta \\ G. F. Schiefelbein
}

October 1993

\author{
Prepared for \\ Westinghouse Hanford Company \\ Waste Tank Safety Program \\ under Contract DE-AC06-76RLO 1830 \\ with the U.S. Department of Energy
}

Pacific Northwest Laboratory

Richland, Washington 99352

\section{MASTER}

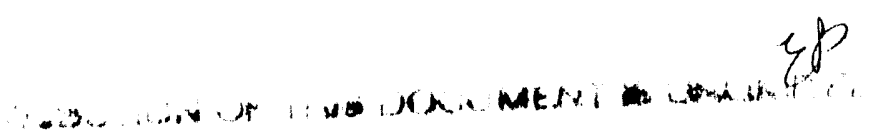




\section{Summary}

The Hanford Ferrocyanide Task Team is addressing issues involving ferrocyanide precipitates in single-shell waste storage tanks (SSTs), in particular the storage of waste in a safe manner. This Task Team, composed of researchers from Westinghouse Hanford Company (WHC), Pacific Northwest Laboratory (PNL), and outside consultants, was formed in response to the need for an updated analysis of safety questions about the Hanford ferrocyanide tanks.

The Ferrocyanide Safety Project at PNL is part of the Waste Tank Safety Program led by WHC. The overall purpose of the WHC program, sponsored by the U.S. Department of Energy's Tank Farm Project Office, is to 1) maintain the ferrocyanide tanks with minimal risk of an accident, 2) select one or more strategies to assure safe storage, and 3) close out the unreviewed safety question (USQ).

This annual report gives the results of the work conducted by PNL in FY 1993 on Task 3, Ferrocyanide Aging Studies, which deals with the aging behavior of simulated ferrocyanide wastes. Aging processes include the dissolution and hydrolysis of nickel ferrocyanides in high $\mathrm{pH}$ aqueous solutions. Investigated were the effects of $\mathrm{pH}$ variation; ionic strength and sodium ion concentration; the presence of anions such as phosphate, carbonate, and nitrate; temperature; and gamma radiation on solubility of ferrocyanide materials including In-Farm-1A, Rev. 4 flowsheet-prepared $\mathrm{Na}_{2} \mathrm{NiFe}(\mathrm{CN})_{6}$.

Vendor-prepared $\mathrm{Na}_{2} \mathrm{NiF} \in(\mathrm{CN})_{6}$ dissolves in aqueous base to give primarily insoluble $\mathrm{Ni}(\mathrm{OH})_{2}$ and soluble $\mathrm{Na}_{4} \mathrm{Fe}(\mathrm{CN})_{6}$. The rate of dissolution of $\mathrm{Na}_{2} \mathrm{NiFe}(\mathrm{CN})_{6}$ in aqueous base increases with

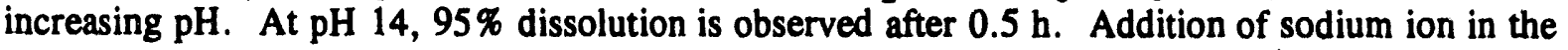
form of $\mathrm{Na}_{2} \mathrm{SO}_{4}$ or $\mathrm{NaNO}_{3}$ suppresses dissolution at $\mathrm{pH} 13$. However, $1 \mathrm{M} \mathrm{Na}^{+}$in the form of $\mathrm{Na}_{2} \mathrm{CO}_{3}, \mathrm{Na}_{3} \mathrm{PO}_{4}$, or SST simulant salts (mixed sodium salts of phosphate, carbonate, nitrate, nitrite, sulfate, and hydroxide) results in an enhancement of the rate of solubilization. At pH 14 these effects are not seen, dissolution being rapid even in the presence of $4 M$ sodium ion. The rate of dissolution is influenced most by base concentration.

Cesium nickel ferrocyanide is not easily dissolved. A material containing a $\mathrm{Cs}_{2} \mathrm{NiFe}(\mathrm{CN})_{6}$ phase (2.3 moles Cs/moles ferrocyanide) was found to be insoluble in up to $4 \mathrm{M} \mathrm{NaOH}$ after stirring for $144 \mathrm{~h}$. In-Farm-1A, Rev. 4 (IF-1A), containing $4.51 \times 10^{-2}$ moles Cs/mole ferrocyanide, dissolved more slowly than the vendor material under identical conditions at both $\mathrm{pH} 13$ and $\mathrm{pH} 14$. The inhibition of IF-1A dissolution may be due to concentration of an insoluble (or less soluble) $\mathrm{Cs}_{2} \mathrm{NiFe}(\mathrm{CN})_{6}$ phase at the particle surface as $\mathrm{Na}_{2} \mathrm{NiFe}(\mathrm{CN})_{6}$ dissolves.

Studies of the hydrolysis of IF-1A in $4 M \mathrm{NaOH}$ at $90^{\circ} \mathrm{C}$ were initiated. Experiments were conducted in the gamma pit with identical controls outside the gamma field. Gamma promotes ferrocyanide hydrolysis. Over $42 \%$ of the cyanide ions were hydrolyzed in the radiation field 
compared with $4.8 \%$ in the control. Similar experiments at $\mathrm{pH} 10$ and $60^{\circ} \mathrm{C}$ indicated IF-1A was insoluble outside of the gamma pit and only very slightly soluble when irradiated. Only a trace of hydrolysis products was detected in the irradiated $\mathrm{pH} 10$ solution. 


\section{Contents}

Summary $\ldots \ldots \ldots \ldots \ldots \ldots \ldots \ldots \ldots \ldots \ldots \ldots \ldots \ldots \ldots \ldots$

Abbreviations $\ldots \ldots \ldots \ldots \ldots \ldots \ldots \ldots \ldots \ldots \ldots \ldots \ldots \ldots \ldots \ldots \ldots \ldots$

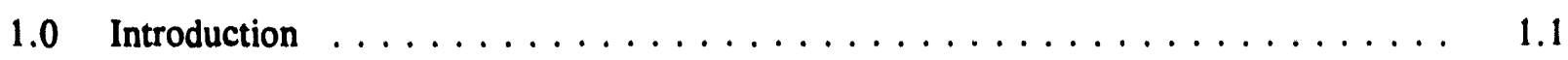

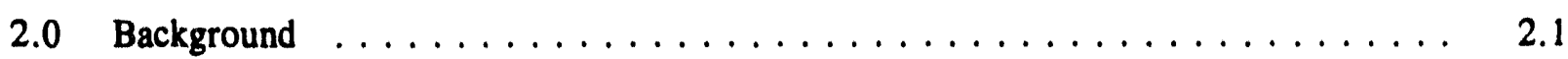

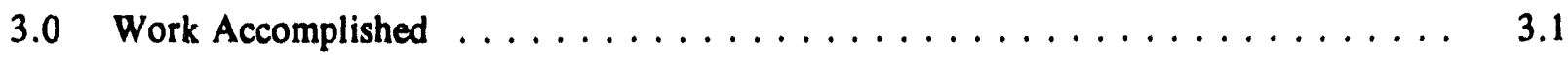

3.1 Dissolution Studies $\ldots \ldots \ldots \ldots \ldots \ldots \ldots \ldots \ldots \ldots \ldots \ldots \ldots \ldots$

3.1.1 Solubility of Vendor-Prepared Ferrocyanide Material $\ldots \ldots \ldots \ldots . \ldots$

3.1.2 Solubility of a $\mathrm{Cs}_{2} \mathrm{NiFe}(\mathrm{CN})_{6}$-Containing Material $\ldots \ldots \ldots \ldots . . \ldots$

3.1.3 Solubility of In-Farm-1A, Rev. 4 Flowsheet Material $\ldots \ldots \ldots \ldots$

3.2 Hydrolysis Studies $\ldots \ldots \ldots \ldots \ldots \ldots \ldots \ldots \ldots \ldots \ldots \ldots \ldots \ldots$

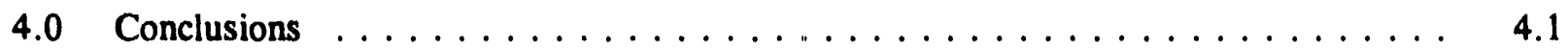

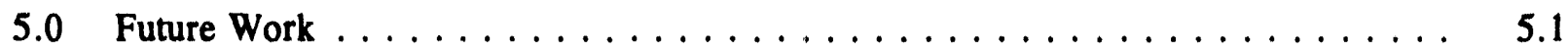

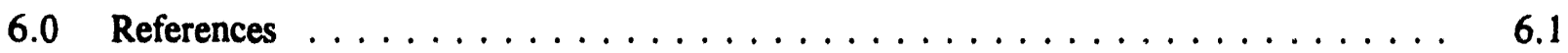




\section{Figures}

3.1 Solubility of Vendor Material at $\mathrm{pH} 13$ as a Function of Sodium Ion

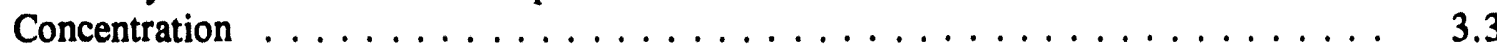

3.2 Solubility of Vendor Material at $\mathrm{pH} 13$ and $1 \mathrm{M} \mathrm{Na}^{+}$in the Presence of Carbonate

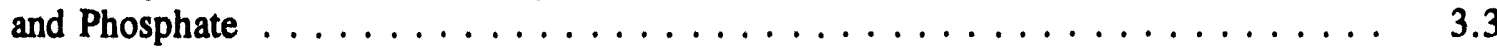

3.3 Dissolution of Vendor Material in $\mathrm{pH} 14$ Solutions $\ldots \ldots \ldots \ldots \ldots$

3.4 Solubility of Vendor Material at $\mathrm{pH} 13,1 \mathrm{M} \mathrm{Na}^{+}$, as a Function of Grams of Ferrocyanide Material Used $\ldots \ldots \ldots \ldots \ldots \ldots \ldots \ldots \ldots \ldots \ldots$

3.5 Solubility of Vendor Material as a Function of Hydroxide Ion to Ferrocyanide Ion Molar Ratio, $1 \mathrm{M} \mathrm{Na}^{+} \ldots \ldots \ldots \ldots \ldots \ldots \ldots \ldots \ldots \ldots$

3.6 Vendor Material and In-Farm-1A Solubility at $\mathrm{pH} 13$ and $\mathrm{pH} 14 \mathrm{With} 1 \mathrm{M} \mathrm{Na}{ }^{+} \ldots 3.10$

3.7 Temperature Dependence of IF-1A Dissolution at $\mathrm{pH} 13,1 \mathrm{M} \mathrm{Na}^{+} \ldots \ldots \ldots$

\section{Tables}

3.1 Moles of Analyte/Gram Ferrocyanide Material Used in Dissolution and

Hydrolysis Experiments.

3.2 Vendor Material Dissolution Data $\ldots \ldots \ldots \ldots \ldots \ldots \ldots \ldots \ldots \ldots \ldots$

3.3 Solution Analytical Data for Reaction Products from Hydrolysis of In-Farm-1A,

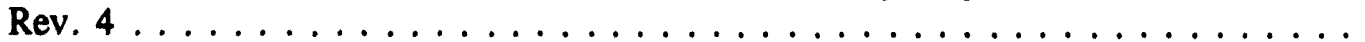




\section{Abbreviations}

$\begin{array}{ll}\text { AA } & \text { atomic absorption spectroscopy } \\ \text { DOE } & \text { U.S. Department of Energy } \\ \text { EDS } & \text { energy dispersive spectroscopy } \\ \text { EDTA } & \text { ethylenediamine tetraacetic acid } \\ \text { EIS } & \text { Environmental Impact Statement } \\ \text { ESEM } & \text { environmental scanning electron microscopy } \\ \text { FECN-14 } & \text { PNL-prepared cesium nickel ferrocyanide material } \\ \text { FTIR } & \text { Fourier transform infrared spectroscopy } \\ \text { GAO } & \text { General Accounting Office } \\ \text { IC } & \text { ion chromatography } \\ \text { IF-1A } & \text { In-Farm-1A, Rev. 4, WHC-prepared flowsheet ferrocyanide material } \\ \text { PNL } & \text { Pacific Northwest Laboratory } \\ \text { SST } & \text { single-shell storage tank at Hanford } \\ \text { TBP } & \text { tributyl phosphate } \\ \text { USQ } & \text { unreviewed safety question } \\ \text { WHC } & \text { Westinghouse Hanford Company } \\ \text { XRD } & \text { x-ray diffraction spectroscopy }\end{array}$




\subsection{Introduction}

The research performed for this project is part of an effort that started in the mid-1980s to characterize the materials stored in the single-shell waste storage tanks (SSTs) at the U.S. Department of Energy (DOE) Hanford Site (Burger 1984; Burger and Scheele 1988, 1991; Scheele et al. 1991). The Environmental Impact Statement (EIS) for the SSTs, Disposal of Hanford Defense High-Level, Transuranic and Tank Wastes (DOE 1987), projected a worst case exposure scenario for an explosion in a ferrocyanide tank to be a short-term radiation dose of 200 mrem to the public. The worst case exposure scenario estimated in a later study by the General Accounting Office (GAO) (Peach 1990) was 1 to 2 orders of magnitude larger than the 1987 EIS. A special Hanford Ferrocyanide Task Team was commissioned in September 1990 to address all technical aspects involving SSTs containing ferrocyanide wastes. In October 1990, Secretary of Energy James D. Watkins announced a Supplemental EIS would be prepared that would contain an updated analysis of the safety questions for the Hanford SSTs (DOE 1990).

The Hanford Ferrocyanide Task Team is composed of technical experts from Westinghouse Hanford Company (WHC), Pacific Northwest Laboratory (PNL) ${ }^{(a)}$, and outside consultants. The Ferrocyanide Task Team reports to the DOE Richland Operations Office, Tank Farm Project Office, through the Ferrocyanide Sarety Progiam function within WHC. WHC has primary program responsibility for work performed by PNL.

The work described in this topical report was performed in FY 1993 as part of the Ferrocyanide Tank Safety Project, Task 3 - Ferrocyanide Aging Studies, and deals with the aging behavior of simulated ferrocyanide tank wastes. The work is a continuation of FY 1992 studies reported previously (Lilga et al. 1992). This report is divided into two activities:

1. Dissolution Studies

2. Hydrolysis Studies.

The report also includes a background section, conclusions from the FY 1993 work, and a discussion of future work.

(a) Operated for the U.S. Department of Energy by Battelle Memorial Institute under Contract DE-AC06-76RLO 1830. 


\subsection{Background}

Radioactive waste resulting from the production of defense nuclear materials has been stored in underground storage tanks at the Hanford Site since the early 1940s. During this time, new technologies were developed, and waste was transferred among tanks to separate different types of waste and to reduce the need for additional tanks. For example, during the 1950s, additional storage volume was required to accommodate the accumulation of high- and low-level radioactive waste while minimizing the construction of additional storage tanks. As a result, Hanford scientists developed a technology to scavenge radiocesium from either process wastes or waste liquids already stored in the SSTs. This process involved the carrier-precipitation of cesium nickel ferrocyanide by addition of sodium ferrocyanide and nickel sulfate. The decontaminated supernate was then pumped to a crib. While providing more storage volume within the tanks, this process added large quantities of ferrocyanide (about 145 metric tons) to the SSTs.

There were three flowsheets used to scavenge the radiocesium from aqueous wastes. The first was used to treat first-cycle waste from the bismuth phosphate process (T-Plant Flowsheet). This generated about $10 \%$ of the total ferrocyanide waste. The second, the U-Plant Flowsheet, treated "metal waste" dissolved in nitric acid after the uranium had been recovered using the tributyl phosphate (TBP) process. The U-Plant Flowsheet produced about $70 \%$ of the total ferrocyanide wastes. The third process, the In-Farm Flowsheet, treated the basic "metal waste" for recovery of uranium. This process produced the remaining $20 \%$ of the total ferrocyanide waste.

T-Plant and U-Plant Flowsheet-treated waste contained substantial metal concentrations that precipitated when neutralized with sodium hydroxide. The ferrocyanide was thereby diluted, assuming that the solids-settling behaviors of the metals and ferrocyanides were approximately the same. It is anticipated that the T-Plant and U-Plant Flowsheets would have a significantly lower concentration of ferrocyanide than In-Farm Flowsheet waste.

As part of subsequent waste management operations, aluminum decladding waste or double-shell slurry from the concentration of reprocessing wastes was added to tanks containing bedded ferrocyanide (Anderson 1990). These solutions were generally quite alkaline with $\mathrm{NaOH}$ concentrations approximately $1 M$.

Of the 177 waste storage tanks on the Site, 149 are SSTs. Records at Hanford show 18 SSTs contain at least $200 \mathrm{~kg}$ (1000 g-mol) of ferrocyanide precipitates. The ferrocyanide content of the individual tanks ranges from $200 \mathrm{~kg}$ up to possibly $16,600 \mathrm{~kg}$ (in Tank BY-104) calculated as the $\mathrm{Fe}(\mathrm{CN})_{6}{ }^{-4}$ anion (Borsheim and Simpson 1991). Other wastes in these tanks probably include significant quantities of sodium nitrate, sodium nitrite, silicates, aluminates, hydroxides, phosphates, sulfates, carbonates, uranium, copper, and calcium in addition to the fission products present from the processing of irradiated fuel.

Ferrocyanide by itself is a stable complex of ferrous ion and cyanide that is considered nontoxic because it does not readily dissociate in aqueous solutions. However, in the laboratory, in the presence of oxidizing materials such as nitrates and/or nitrites, dry ferrocyanide can be made to explode by heating to temperatures above $280^{\circ} \mathrm{C}$ or by an electrical spark of sufficient energy (Burger and 
Scheele 1991). The explosive nature of ferrocyanide in the presence of an oxidizer has been known for decades, but the conditions under which the compound can undergo an uncontrolled exothermic reaction have not been thoroughly studied. Explosion propagation properties for large quantities of the material are unknown, and the effects of moisture content and other diluents (or possible catalysts or initiators) that may be present in the tanks are currently being studied. Because the scavenging process involved the precipitation of ferrocyanide from solutions containing nitrates and nitrites, it is likely that an intimate mixture of ferrocyanides and nitrates/nitrites exists in parts of some of the SSTs.

The ultimate goal of the Aging Studies task is to understand the long-term behavior of ferrocyanide tank wastes in the SST environments. This report characterizes the dissolution and hydrolysis of ferrocyanide waste simulants in aqueous base under a variety of conditions. A possible mechanism for delivery of caustic to bedded ferrocyanide layers is the topic of a recent model prepared in a parallel task (McGrail et al. 1993). This work provides baseline data that will be useful as actual SST samples are obtained and analyzed. These results will directly assist in determining 1) which one or more strategies will assure safe storage and 2) how to close out the unreviewed safety question (USQ) and resolve the safety issue. 


\subsection{Work Accomplished}

The work conducted in FY 1993 for Task 3, Ferrocyanide Aging Studies, is discussed below. Aging is defined as any process that may have altered the chemical nature of the ferrocyanide waste. Primary aging routes investigated are dissolution of alkali metal nickel ferrocyanides, shown in Eq. (1) for the sodium compound, and hydrolysis of ferrocyanide ion, shown in Eq. (2) (Robuck and Luthy 1989).

$$
\begin{aligned}
& \mathrm{Na} 2 \mathrm{NiFo}\left(\mathrm{CN}_{6}+2 \mathrm{NaOH}\right. \longrightarrow \mathrm{Na}_{4} \mathrm{Fe}\left(\mathrm{CNN}_{6}+\mathrm{Ni}(\mathrm{OH})_{2}\right. \\
& \mathrm{Na}_{4} \mathrm{Fe}(\mathrm{CN})_{6}+2 \mathrm{NaOH}+11 \mathrm{H}_{2} \mathrm{O}+1 / 6 \mathrm{O}_{2} \longrightarrow 6 \mathrm{NH}_{3}+6 \mathrm{NaHCO}_{2}+1 / 3 \mathrm{Fe}_{3} \mathrm{O}_{4}
\end{aligned}
$$

\subsection{Dissolution Studies}

Dissolution studies in FY 1993 were conducted on three ferrocyanide-containing materials. Studies of the vendor material, with approximate composition $\mathrm{Na}_{2} \mathrm{NiFe}(\mathrm{CN})_{6} \cdot \mathrm{Na}_{2} \mathrm{SO}_{4} \cdot 4.5 \mathrm{H}_{2} \mathrm{O}$, were continued from FY 1992 work. In addition, two cesium-containing ferrocyanide materials, PNL-prepared $\mathrm{Cs}_{2} \mathrm{NiFe}(\mathrm{CN})_{6}$ (FECN-14) and the Westinghouse-prepared flowsheet material In-Farm-1A, Rev. 4 (IF-1A), were investigated. Table 3.1 shows the compositions of these materials as determined by atomic absorption (AA) and Fourier transform infrared (FTIR) spectroscopy analyses of samples dissolved in ethylenediamine/ethylenediamine tetraacetic acid (EDTA).

\subsubsection{Solubility of Vendor-Prepared Ferrocyanide Material}

Studies of vendor material solubility, conducted in FY 1993 for Task 3, Ferrocyanide Aging Studies, are continued from FY 1992 work previously reported (Lilga et al. 1992; Babad et al. 1993). In a typical experiment, $1 \mathrm{~g}$ of the vendor material was stirred in $50 \mathrm{~mL}$ of aqueous base for $144 \mathrm{~h}$.

Table 3.1. Moles of Analyte/Gram Ferrocyanide Material Used in Dissolution and Hydrolysis Experiments. Analyses of $\mathrm{Cs}, \mathrm{Fe}, \mathrm{Ni}$, and $\mathrm{Na}$ by $\mathrm{AA} ; \mathrm{Fe}(\mathrm{CN})_{6}^{-4}$ by FTIR.

\begin{tabular}{|l|l|l|l||}
\hline Analyte & moles/g Vendor & moles/g FECN-14 & moles/g IF-1A \\
\hline $\mathrm{Cs}$ & - & $3.06 \times 10^{-3}$ & $2.96 \times 10^{-5}$ \\
\hline $\mathrm{Fe}$ & $1.93 \times 10^{-3}$ & $1.33 \times 10^{-3}$ & $6.56 \times 10^{-4}$ \\
\hline $\mathrm{Ni}$ & $2.00 \times 10^{-3}$ & $1.51 \times 10^{-3}$ & $1.00 \times 10^{-3}$ \\
\hline $\mathrm{Na}$ & $7.36 \times 10^{-3}$ & $3.35 \times 10^{-4}$ & $1.02 \times 10^{-2}$ \\
\hline $\mathrm{Fe}(\mathrm{CN})_{6}{ }^{-4}$ & $1.86 \times 10^{-3}$ & $1.30 \times 10^{-3}$ & $7.13 \times 10^{-4}$ \\
\hline
\end{tabular}


Solution samples were periodically taken and analyzed for ir on (ferrocyanide anion) by AA. The reaction products were identified with use of FTIR, powder X-ray diffraction (XRD), and energy dispersive spectroscopies (EDS) combined with environmental scanning electron microscopy (ESEM).

In FY 1992 work, it was demonstrated that the vendor-prepared ferrocyanide material reacts with $\mathrm{NaOH}$ to form insoluble $\mathrm{Ni}\left(\mathrm{OH}_{2}\right.$ and soluble $\mathrm{Na} 4 \mathrm{Fe}(\mathrm{CN})_{6}$ according to Eq. (1). The rate of dissolution of $\mathrm{Na}_{2} \mathrm{NiFe}(\mathrm{CN})_{6}$ in aqueous base was found to increase with increasing $\mathrm{pH}$. At pH 14, $95 \%$ dissolution was observed after $0.5 \mathrm{~h}$. Addition of $1 \mathrm{M} \mathrm{Na}^{+}$ions in the form of $\mathrm{Na}_{2} \mathrm{SO}_{4}$ suppressed dissolution at $\mathrm{pH}$ 13. However, $1 \mathrm{M} \mathrm{Na}{ }^{+}$in the form of a mixture of salts $\mathrm{NaNO}_{3}$, 80.47 wt \%; $\mathrm{NaNO}_{2}, 4.37 \mathrm{wt} \% ; \mathrm{Na}_{2} \mathrm{CO}_{3}, 1.52 \mathrm{wt} \% ; \mathrm{NaOH}, 3.12 \mathrm{wt} \% ; \mathrm{Na}_{2} \mathrm{SO}_{4}, 1.48$ wt \%; $\left.\mathrm{Na}_{3} \mathrm{PO}_{4}, 9.04 \mathrm{wt} \%\right)$, simulating the composition of a typical SST, resulted in an enhancement of the rate of dissolution The enhancement may arise from buffering of the solution by phosphate since the $\mathrm{pH}$ of the solution was nearly unchanged at the end of the experiment. Even when the solution was not stirred, dissolution was relatively rapid. Approximately $40 \%$ of the $\mathrm{Na}_{2} \mathrm{NiFe}(\mathrm{CN})_{6}$ dissolved in $24 \mathrm{~h}$ and $90 \%$ after $140 \mathrm{~h}$ in an unstirred $\mathrm{pH} 13$ solution containing SST salts.

In FY 1993, sodium ion dependence was further investigated. At pH 13, addition of sodium nitrate suppresses dissolution; increasing sodium concentration results in decreasing rates of reaction (Figure 3.1). Although ionic strength also increases with concentration, the effect is most likely attributed to sodium ion concentration (activity). For example, at $1 \mathrm{M} \mathrm{Na}^{+}, \mathrm{Na}_{2} \mathrm{SO}_{4}$ results in a dissolution rate faster than $\mathrm{NaNO}_{3}$, even though its ionic strength is greater than that of the nitrate solution. The sodium activity is lower in the presence of doubly charged sulfate, leading to relatively higher rates.

Carbonate and phosphate anions promote dissolution at pH 13. Figure 3.2 illustrates the enhanced rates when $1 \mathrm{M} \mathrm{Na}{ }^{+}$is present as $\mathrm{Na}_{2} \mathrm{CO}_{3}, \mathrm{Na}_{3} \mathrm{PO}_{4}$, or as SST simulant salts. Atomic absorption data indicate that the carbonate dissolution follows closely the phosphate dissolution, but analysis of the reaction products indicates otherwise. From FTIR analysis, the insoluble fraction at the end of the phosphate dissolution is not the starting material but, rather, a re-precipitated ironcyanide of unknown composition. From AA measurements, the re-precipitated material represents about $6 \%$ of the iron introduced. However, the remaining insoluble ferrocyanide fraction in the carbonate dissolution is primarily the expected unreacted vendor ferrocyanide containing only a small quantity of the re-precipitated material. Dissolution according to Eq. (1) is apparently more rapid in phosphate than in carbonate media, but the precipitation reaction gives the appearance, in plots of soluble iron as a function of time, that the rates are similar. The insoluble material from the SST simulant salt-containing experiment also showed a small amount of re-precipitated iron-cyanides.

The accelerated rate in the SST simulant salt-containing solutions was originally thought to arise from phosphate buffering since the $\mathrm{pH}$ (glass electrode) dropped only 0.1 unit, from 13.0 to 12.9 (Lilga et al. 1992). However, independent experiments containing only carbonate or phosphate showed $\mathrm{pH}$ drops of about 0.6 units in each case, not consistent with the buffering hypothesis (Table 3.2). This pH drop is consistent with the use of two equivalents of hydroxide for each equivalent of ferrocyanide dissolved, as expected from Eq. (1) (see below). Precipitation of the highly insoluble nickel phosphate might be expected to increase the rate of dissolution; however, its presence has not yet been verified. Absorption bands possibly arising from phosphate appear in FTIR spectra 


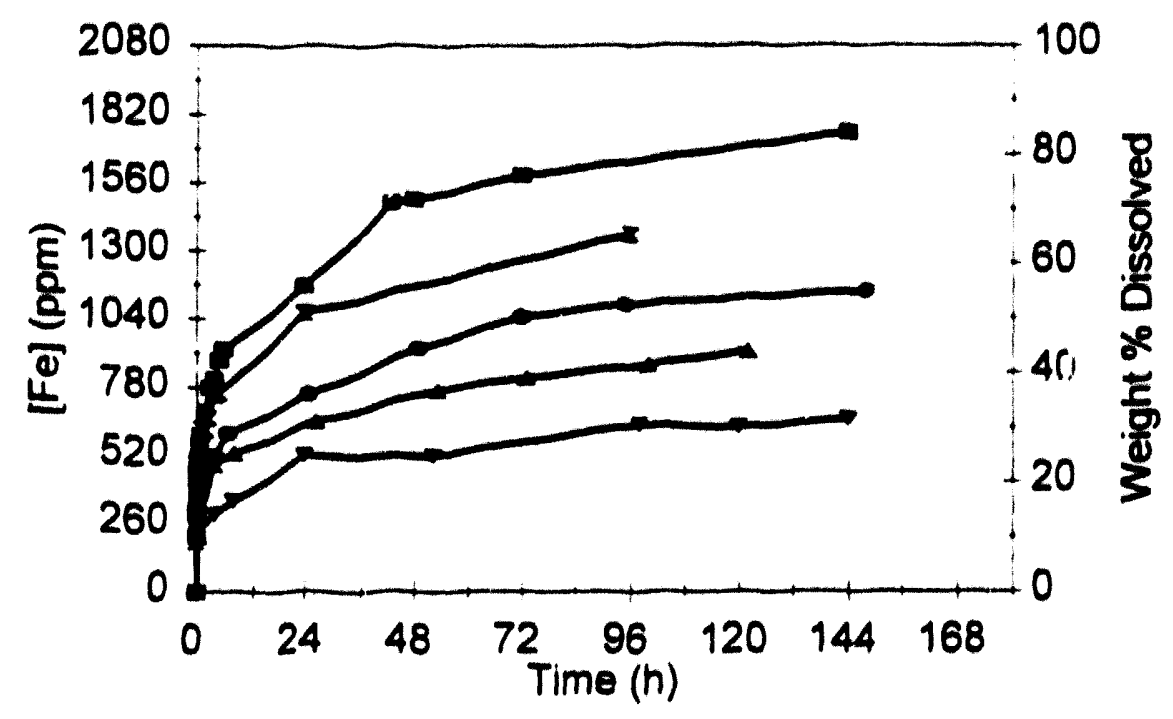

$-\mathrm{NaOH}(0.1 \mathrm{M} \mathrm{Na}+)-\mathrm{NaNO} 3(1 \mathrm{MNa}+)-\mathrm{NaNO} 3(4 \mathrm{M} \mathrm{Na}+)$ $-\mathrm{NaNO} 3(6 \mathrm{M} \mathrm{Na}+)-\mathrm{Na} 2 \mathrm{SO} 4(1 \mathrm{M} \mathrm{Na}+)$

Figure 3.1. Solubility of Vendor Material at pH 13 as a Function of Sodium Ion Concentration

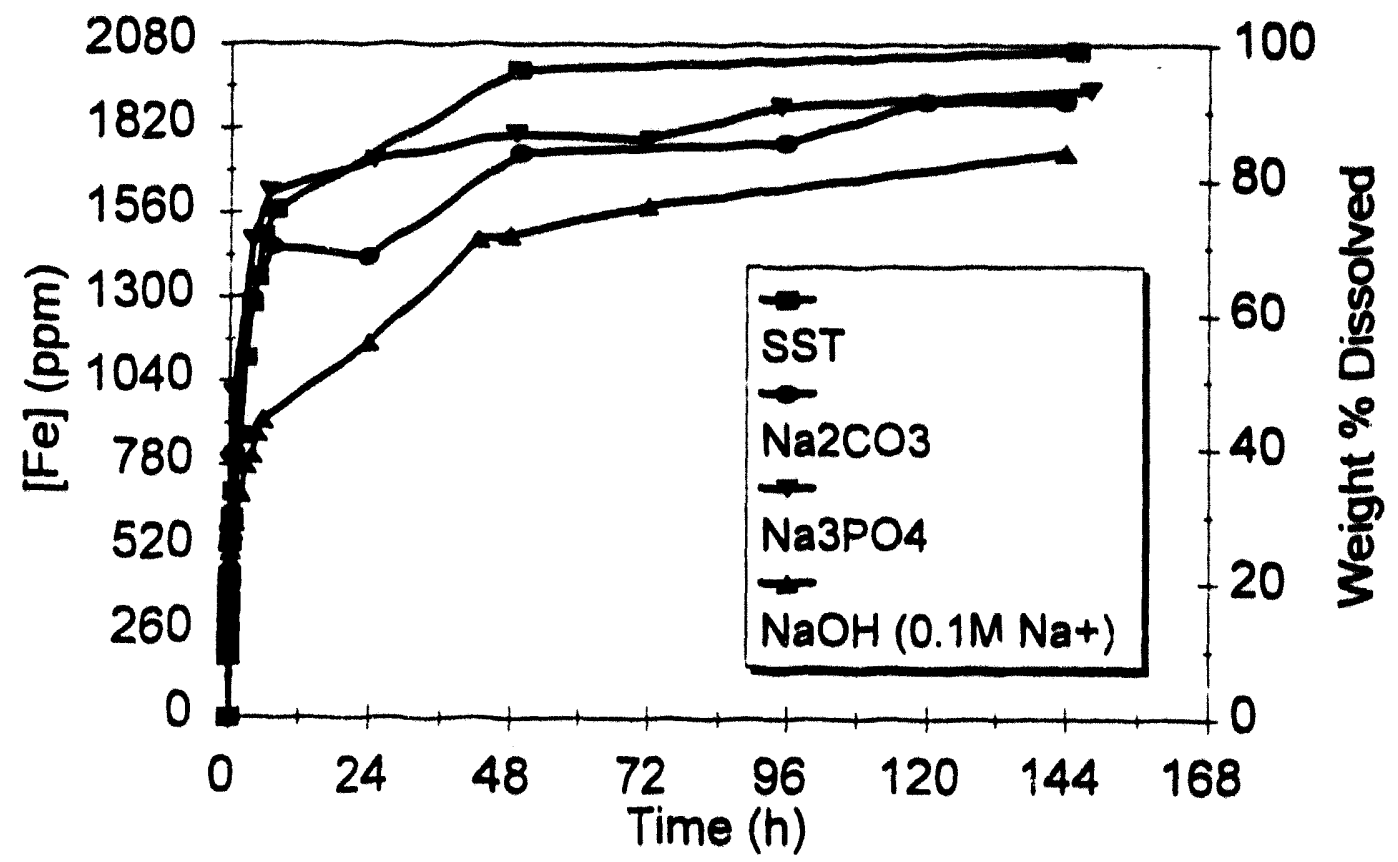

Figure 3.2. Solubility of Vendor Material at pH 13 and $1 \mathrm{M} \mathrm{Na}{ }^{+}$in the Presence of Carbonate and Phosphate 
Table 3.2. Vendor Material Dissolution Data

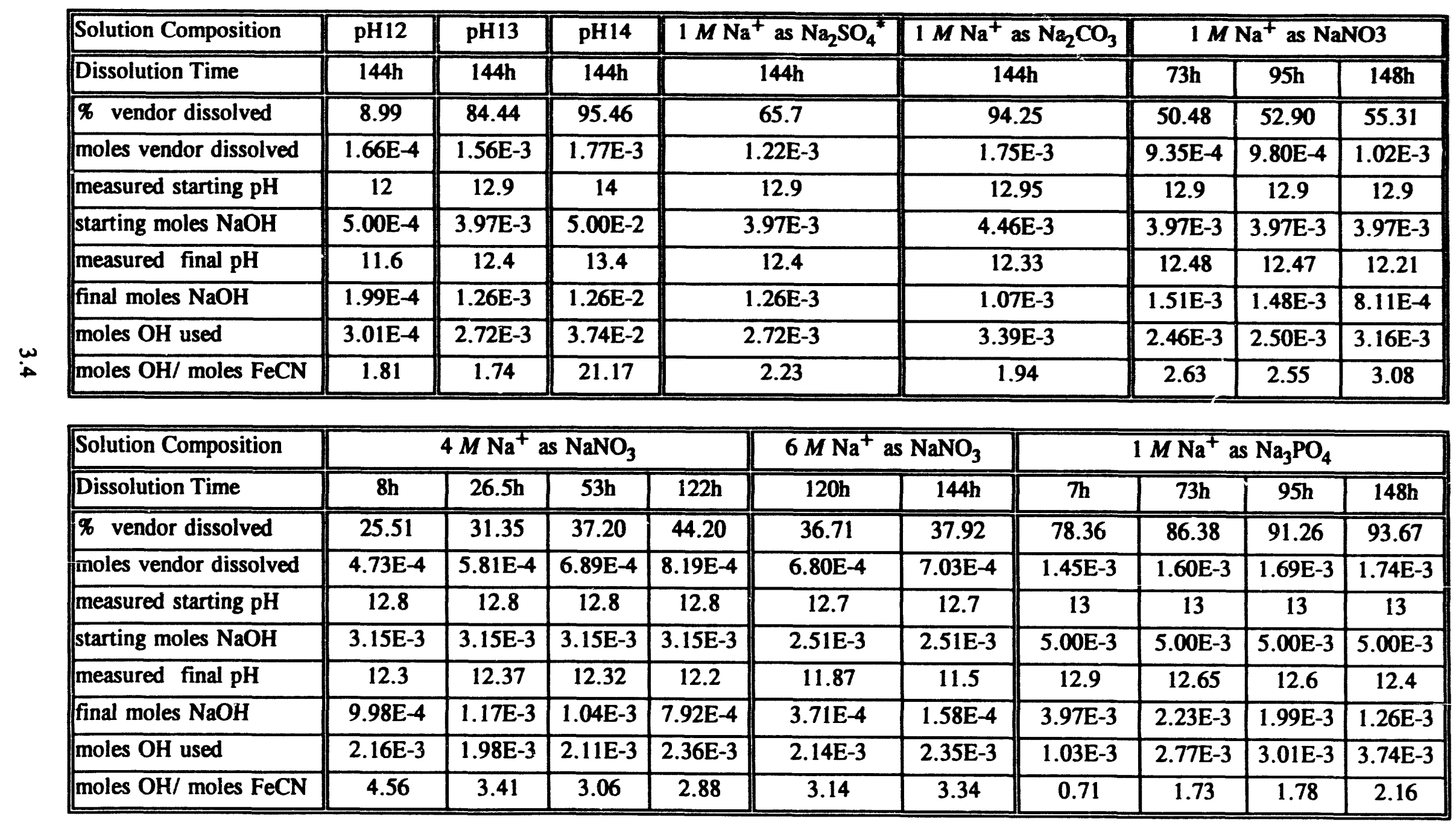


Table 3.2. (contd)

\begin{tabular}{|l|c|c|c|c|c|c|c|c|c|}
\hline Solution Composition & \multicolumn{3}{|c|}{$0.1 \mathrm{~g}$ Vendor Material, $1 \mathrm{M} \mathrm{Na}{ }^{+}$as NaNO } & \multicolumn{3}{|c|}{$0.25 \mathrm{~g}$ Vendor Material, $1 \mathrm{M} \mathrm{Na}^{+}$as $\mathrm{NaNO}_{3}$} \\
\hline Dissolution Time & $7 \mathrm{~h}$ & $24 \mathrm{~h}$ & $48 \mathrm{~h}$ & $72 \mathrm{~h}$ & $144 \mathrm{~h}$ & $8 \mathrm{~h}$ & $26.5 \mathrm{~h}$ & $53 \mathrm{~h}$ & $122 \mathrm{~h}$ \\
\hline \hline \% vendor dissolved & 86.96 & 91.79 & 94.69 & 99.52 & 99.52 & 68.79 & 81.93 & 89.47 & 87.54 \\
\hline moles vendor dissolved & $1.61 \mathrm{E}-4$ & $1.70 \mathrm{E}-4$ & $1.75 \mathrm{E}-4$ & $1.84 \mathrm{E}-4$ & $1.84 \mathrm{E}-4$ & $3.19 \mathrm{E}-4$ & $3.79 \mathrm{E}-4$ & $4.14 \mathrm{E}-4$ & $4.05 \mathrm{E}-4$ \\
\hline measured starting pH & 12.9 & 12.9 & 12.9 & 12.9 & 12.9 & 12.9 & 12.9 & 12.9 & 12.9 \\
\hline starting moles $\mathrm{NaOH}$ & $3.97 \mathrm{E}-3$ & $3.97 \mathrm{E}-3$ & $3.97 \mathrm{E}-3$ & $3.97 \mathrm{E}-3$ & $3.97 \mathrm{E}-3$ & $3.97 \mathrm{E}-3$ & $3.97 \mathrm{E}-3$ & $3.97 \mathrm{E}-3$ & $3.97 \mathrm{E}-3$ \\
\hline mcasured final pH & 12.53 & 12.63 & 12.72 & 12.52 & 12.42 & 12.49 & 12.54 & 12.5 & 12.42 \\
\hline final moles $\mathrm{NaOH}$ & $1.69 \mathrm{E}-3$ & $2.13 \mathrm{E}-3$ & $2.62 \mathrm{E}-3$ & $1.66 \mathrm{E}-3$ & $1.32 \mathrm{E}-3$ & $1.55 \mathrm{E}-3$ & $1.73 \mathrm{E}-3$ & $1.58 \mathrm{E}-3$ & $1.32 \mathrm{E}-3$ \\
\hline moles $\mathrm{OH}$ used & $2.28 \mathrm{E}-3$ & $1.84 \mathrm{E}-3$ & $1.35 \mathrm{E}-3$ & $2.32 \mathrm{E}-3$ & $2.66 \mathrm{E}-3$ & $2.43 \mathrm{E}-3$ & $2.24 \mathrm{E}-3$ & $2.39 \mathrm{E}-3$ & $2.66 \mathrm{E}-3$ \\
\hline moles $\mathrm{OH} /$ moles FeCN & 14.14 & 10.81 & 7.68 & 12.56 & 14.41 & 7.62 & 5.90 & 5.77 & 6.55 \\
\hline
\end{tabular}

* Sufficient amount of compound added to $\mathrm{NaOH}$ to yield $\left[\mathrm{Na}^{+}\right]$shown. 
of the insoluble solids, but assignment to a nickel phosphate phase has not been possible. Powder XRD spectra for independently prepared nickel phosphate show this material to be amorphous, rendering XRD detection impossible. Nickel hydroxide has been positively identified in the insoluble solids by FTIR and XRD.

The influence of sodium ion concentration and the presence of various anions is minimal in $\mathrm{pH} 14$ solution. Figure 3.3 compares data from experiments at $\mathrm{pH} 14$ with $1 \mathrm{M} \mathrm{Na}^{+}$, as sodium hydroxide; $4 \mathrm{M} \mathrm{Na}^{+}$, adjusted with sodium nitrate; and $2 \mathrm{M} \mathrm{Na}{ }^{+}$, adjusted with sodium carbonate. Unlike the pH 13 results, no effect is seen. Dissolution is over $90 \%$ complete within $1 \mathrm{~h}$ in each solution. These results indicate that dissolution is more sensitive to hydroxide ion concentration than to sodium ion concentration.

The dependence of the rate of dissolution on initial quantity of vendor material present was investigated at pH 13. Results of experiments using $1.0 \mathrm{~g}, 0.25 \mathrm{~g}$, and $0.1 \mathrm{~g}$ vendor material each in $50 \mathrm{~mL}$ of a pH 13 solution containing $1 \mathrm{M} \mathrm{Na}^{+}$adjusted with $\mathrm{NaNO}_{3}$ are shown in Figure 3.4. Normalized to a weight percent dissolved basis, more rapid dissolution is observed when less ferrocyanide is present or, in other words, when the hydroxide ion to ferrocyanide ion molar ratio is high. Figure 3.5 shows the same $\mathrm{pH} 13$ data for the first $12 \mathrm{~h}$ of reaction compared with a $\mathrm{pH} 14$ dissolution experiment. At a hydroxide ion to ferrocyanide ion molar ratio of 27.0 , the $\mathrm{pH} 14$ dissolution is observed to be much more rapid than in $\mathrm{pH} 13$ solution. Although the hydroxide ion to ferrocyanide ion molar ratio determines the rate at $\mathrm{pH} 13$, the overall hydroxide concentration is still the major factor influencing the rate of dissolution.

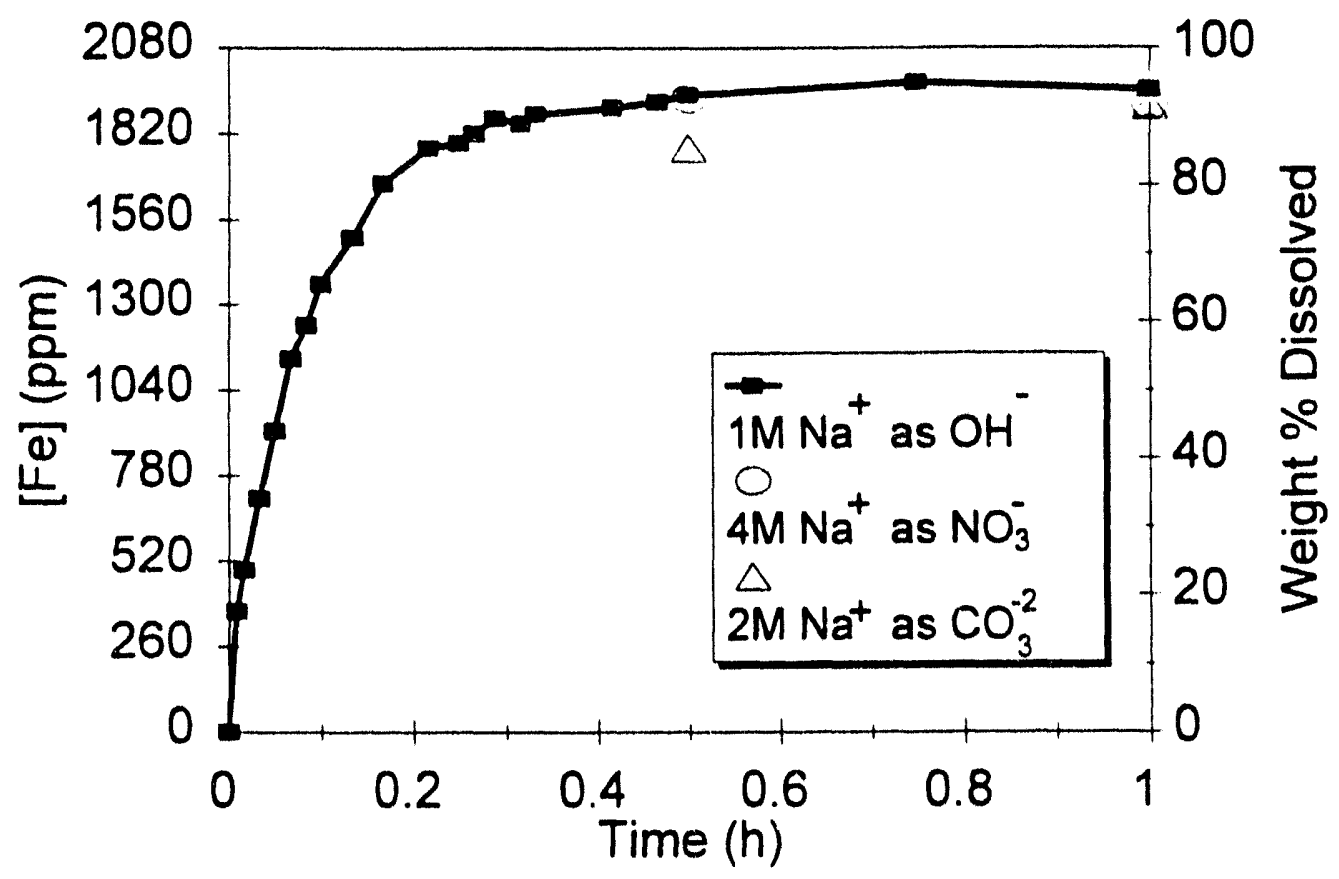

Figure 3.3. Dissolution of Vendor Material in pH 14 Solutions 


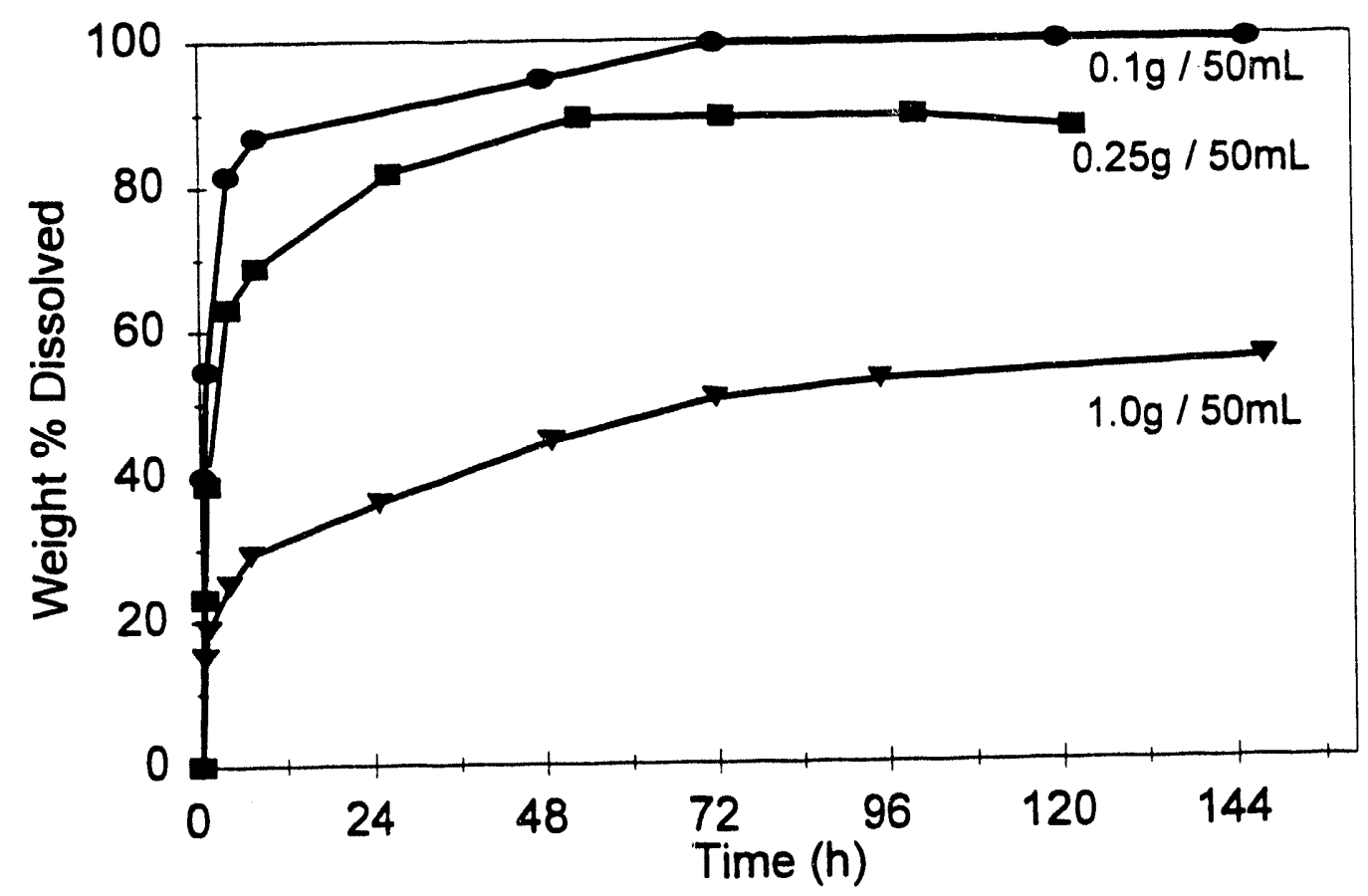

Figure 3.4. Solubility of Vendor Material at $\mathrm{pH} 13,1 \mathrm{M} \mathrm{Na}^{+}$, as a Function of Grams of Ferrocyanide Material Used

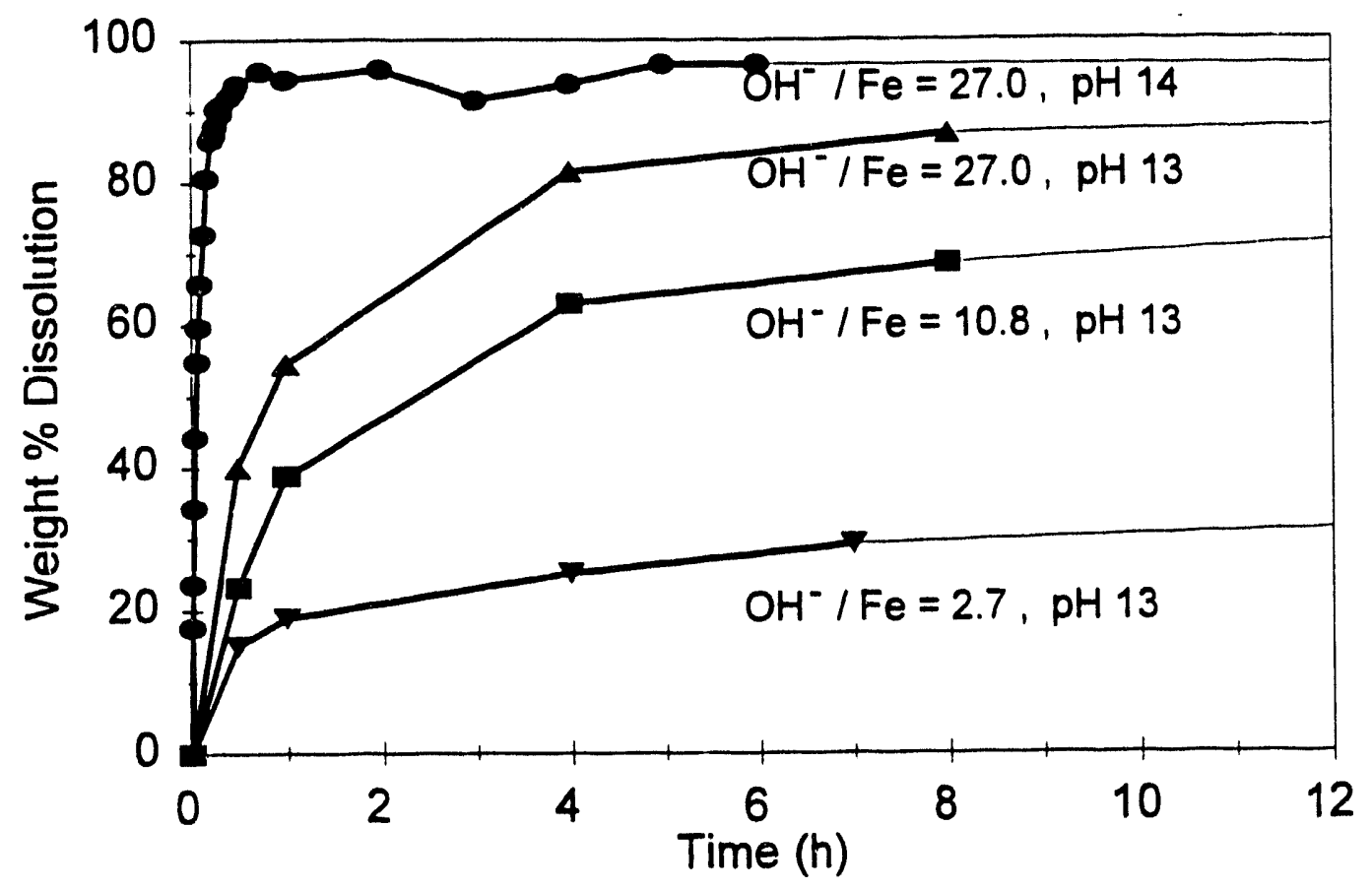

Figure 3.5. Solubility of Vendor Material as a Function of Hydroxide Ion to Ferrocyanide Ion Molar Ratio, $1 \mathrm{M} \mathrm{Na}^{+}$ 
Table 3.2 summarizes $\mathrm{pH}$ data taken during vendor material dissolution experiments conducted in FY 1992 and FY 1993. Moles of hydroxide consumed, as estimated from pH meter measurements (glass electrode), are ratioed against the moies of vendor material dissolved. Any inaccuracies in the measured $\mathrm{pH}$ values ( 0.1 units) will result in variations in the $\mathrm{OH}^{-} /$ferrocyanide mole ratio of about 0.5 to 1; the calculated ratio is sensitive to the accuracy of the pH measurement. In most cases this ratio is approximately 2 as predicted from the stoichiometry of the dissolution reaction (Eq. 1). Ratios greatly different from 2 are observed in $\mathrm{pH} 14$ solution and in cases where only a small amount of dissolution (smali change in $\left[\mathrm{OH}^{-}\right]$) has occurred, such as when 0.1 and $0.25 \mathrm{~g}$ of vendor material (as opposed to $1 \mathrm{~g}$ ) were used. High sodium nitrate concentrations had relatively little effect on the calculated $\mathrm{OH}^{-} /$ferrocyanide mole ratios, indicating that measured changes in $\mathrm{pH}$ may be accurate even though absolute $\mathrm{pH}$ values from glass electrode measurements in these high sodium solutions are uncertain.

\subsubsection{Solubility of a $\mathrm{Cs}_{2} \mathrm{NiFe}(\mathrm{CN})_{6}$ Containing Material}

Dissolution tests were conducted with the PNL-prepared material FECN-14. Analyses indicate this material contains 2.3 moles $\mathrm{Cs} /$ mole ferrocyanide anion (Table 3.1) and has a $\mathrm{Ni} / \mathrm{Fe}$ mole ratio of 1.14. Experiments show that $\mathrm{Cs}_{2} \mathrm{NiFe}(\mathrm{CN})_{6}$ remains completely insoluble in $0.1 \mathrm{M}$ to $4.0 \mathrm{M} \mathrm{NaOH}$ solutions after stirring for $144 \mathrm{~h}$ at room temperature. Infrared spectra indicate that the supernate solution consists of $\mathrm{NaNO}_{3}$ and $\mathrm{NaOH}$, with no dissolved $\mathrm{Fe}(\mathrm{CN})_{6}^{-4}$. Atomic absorption analyses also indicated that iron was not present in the supernate solution. The insoluble material remaining after $144 \mathrm{~h}$ had the same FTIR spectrum as the starting material. These results suggest that if a $\mathrm{Cs}_{2} \mathrm{NiFe}(\mathrm{CN})_{6}$ phase is present in ferrocyanide waste, it would not easily dissolve when contacted with caustic. These results also suggest that $\mathrm{NaOH}$ is not a suitable choice for dissolving ferrocyanide tank samples for subsequent analysis. The FECN-14 material dissolved readily in the ethylenediamine/EDTA solvent used for FTIR and AA analyses.

The reason for the insolubility of $\mathrm{Cs}_{2} \mathrm{NiFe}(\mathrm{CN})_{6}$, in light of the solubility of the sodium analog, is unknown at this time. Possible explanations include a greater lattice energy than the sodium analog, a different crystal structure, and fewer defects or smaller channels through which base can enter the crystal lattice. The literature indicates that alkali metal nickel ferrocyanides are isomorphous regardless of composition, having cubic structures with unit cell parameters between 9.9 and $10.2 \AA$ (Loos-Neskovic et al. 1984, 1989; Loos-Neskovic and Fedoroff 1989). In a constant-sized unit cell, replacement of sodium with the larger cesium cation could block channels within the extended ferrocyanide structure. Thus, while dissolution may be thermodynamically favorable, the process could be kinetically slow.

\subsubsection{Solubility of In-Farm-1A, Rev. 4 Flowsheet Material}

Dried IF-1A, a top-layer In-Farm Flowsheet simulant (Jeppson and Wong 1993), was used for dissolution and hydrolysis studies. Upon drying to constant weight at $60^{\circ} \mathrm{C}$ under vacuum, the material lost $46 \%$ of its weight as water. Analytical results (iron, cesium, nickel, and sodium by AA, ferrocyanide anion by FTIR) for the dried simulant dissolved in ethylenediamine/EDTA solution were summarized in Table 3.1. This material contains $4.51 \times 10^{-2}$ moles Cs/mole ferrocyanide (as determined from AA data). The $\mathrm{Cs} / \mathrm{Na}$ mole ratio of $2.9 \times 10^{-3}$ is smaller than the expected ratio of $9 \times 10^{-3}$ based on the flowsheet recipe. Most of the cesium apparently is associated with the bottom 
ferrocyanide layer obtained in the flowsheet preparation. Infrared and AA data are consistent for iron and ferrocyanide anion, giving a $\mathrm{Fe}(\mathrm{CN})_{6}{ }^{-4} / \mathrm{Fe}$ ratio of 1.09 , showing that iron is predominantly present in the form of ferrocyanide anion. The Ni/Fe ratio of 1.52 is greater than the stoichiometric ratio of 1.0 observed in the vendor material and FECN-14. The IF-1A material either contains other nickel compounds, such as nickel phosphate, or contains ion-exchanged nickel within the ferrocyanide phase.

Two dissolution experiments, one initially containing $1 M$ sodium ion at $\mathrm{pH} 13\left(\mathrm{NaNO}_{3}\right.$ used to adjust $\left.\left[\mathrm{Na}^{+}\right]\right)$and the other at $\mathrm{pH} 14\left(1 \mathrm{M} \mathrm{Na}^{+}\right.$as $\left.\mathrm{NaOH}\right)$, were conducted in which $4.29 \mathrm{~g}$ of IF-1A were stirred in $75 \mathrm{~mL}$ of caustic solution. The quantities were chosen to give about the same final ferrocyanide concentration (if all dissolved) and the same ferrocyanide/hydroxide mole ratio as in previous experiments utilizing the vendor material. Iron and cesium concentrations in periodically drawn solution samples were determined by AA.

Dissolution (solution iron concentration) as a function of time is shown in Figure 3.6, which compares the behavior of IF-1A with that of the vendor material under similar conditions. The rate of dissolution of IF-1A is generally suppressed relative to the vendor material; initial dissolution at pH 14 is rapid with a slow increase to about $85 \%$ dissolution after $144 \mathrm{~h}$, while the vendor material was over $90 \%$ dissolved after $0.5 \mathrm{~h}$. In $\mathrm{pH} 13$ solution, the IF-1A material dissolved very slowly with only about $18 \%$ in solution after $144 \mathrm{~h}$. The suppressed rates are probably not a result of higher sodium ion concentrations arising from dissolution of salts from the IF-1A material (which would increase the $\left[\mathrm{Na}^{+}\right]$about $0.5 \mathrm{M}$ ). The rate of dissolution of IF-1A in pH 13 solution is lower than that of the vendor material in a pH $13,6 \mathrm{M} \mathrm{Na}^{+}$solution, which reached about $30 \%$ after $144 \mathrm{~h}$ (Figure 3.1).

None of the solution samples contained cesium; i.e., cesium is not solubilized even in pH 14 solution. Ferrocyanides are known to be good ion exchange materials for cesium sorption (Campbell et al. 1990; Loos-Neskovic and Fedoroff 1989), and it is likely that any cesium liberated by ferrocyanide dissolution would exchange back into the solid to form a $\mathrm{Cs}_{2} \mathrm{NiFe}(\mathrm{CN})_{6}$ or $\mathrm{NaCsNiFe}(\mathrm{CN})_{6}$ phase. Accumulation of cesium at the particle surface may explain the suppressed dissolution, since $\mathrm{FECN}-14$, containing $\mathrm{Cs}_{2} \mathrm{NiFe}(\mathrm{CN})_{6}$, was found to be insoluble in up to $4 M \mathrm{NaOH}$.

The temperature dependence of IF-1A dissolution was investigated at $60^{\circ} \mathrm{C}$ and $90^{\circ} \mathrm{C}$ using $\mathrm{pH} 13$ solutions adjusted to $1 \mathrm{M}$ sodium ion with $\mathrm{NaNO}_{3}$. These experiments were conducted in Teflon labware. Figure 3.7 illustrates the increase in soluble iron (sodium ferrocyanide) with time. The extent of dissolution increases with increasing temperature. At $25^{\circ} \mathrm{C}$, after $144 \mathrm{~h}$, about 18 wt \% of the ferrocyanide is dissolved. At $60^{\circ} \mathrm{C}$ and $90^{\circ} \mathrm{C}$, the reaction apparently approaches equilibrium dissolution of about $47 \%$ and $63 \%$, respectively. Atomic absorption analysis again shows no dissolved cesium in any of the reaction solutions. 

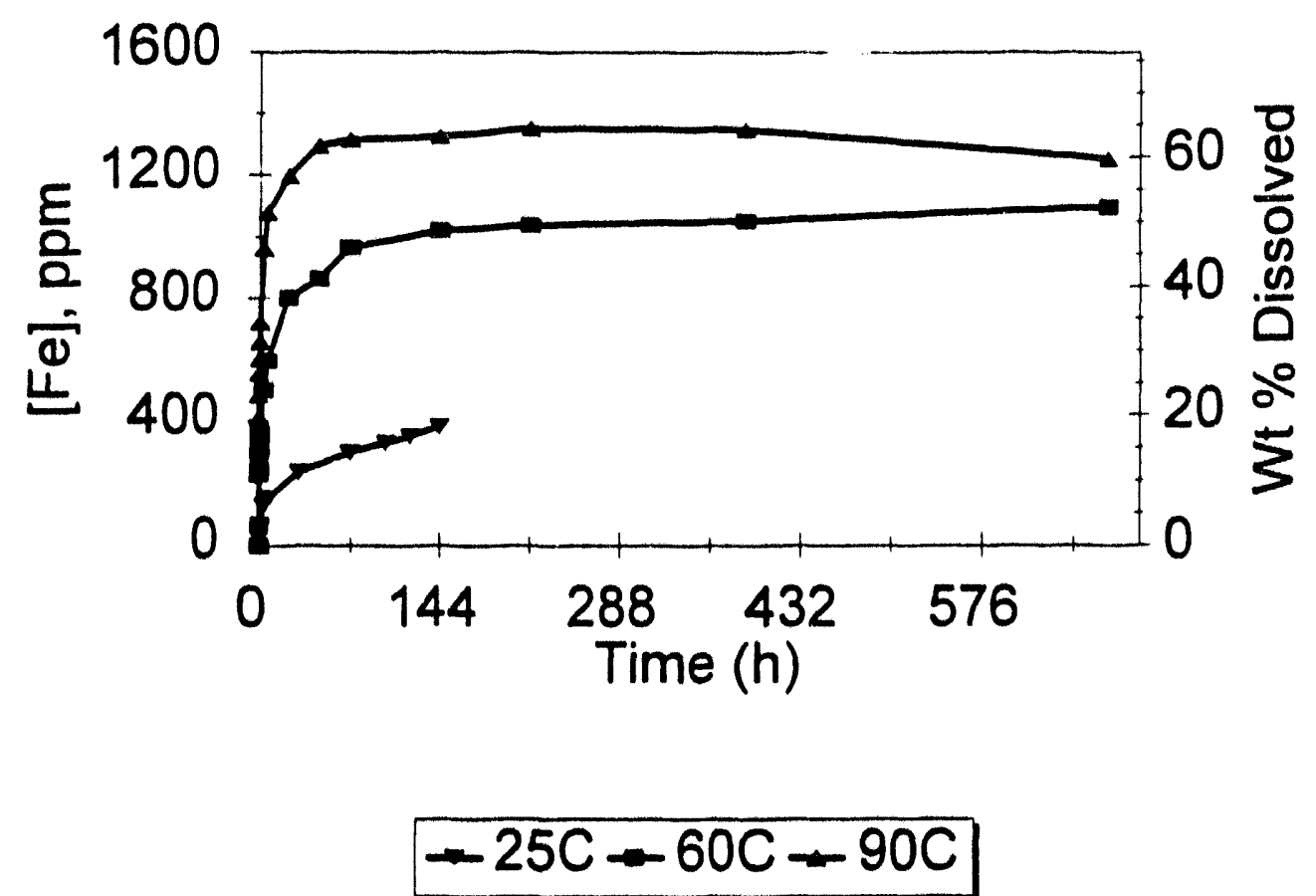

Figure 3.6. Vendor Material and In-Farm- $1 \mathrm{~A}$ Solubility at pH 13 and $\mathrm{pH} 14$ With $1 \mathrm{M} \mathrm{Na}^{+}$

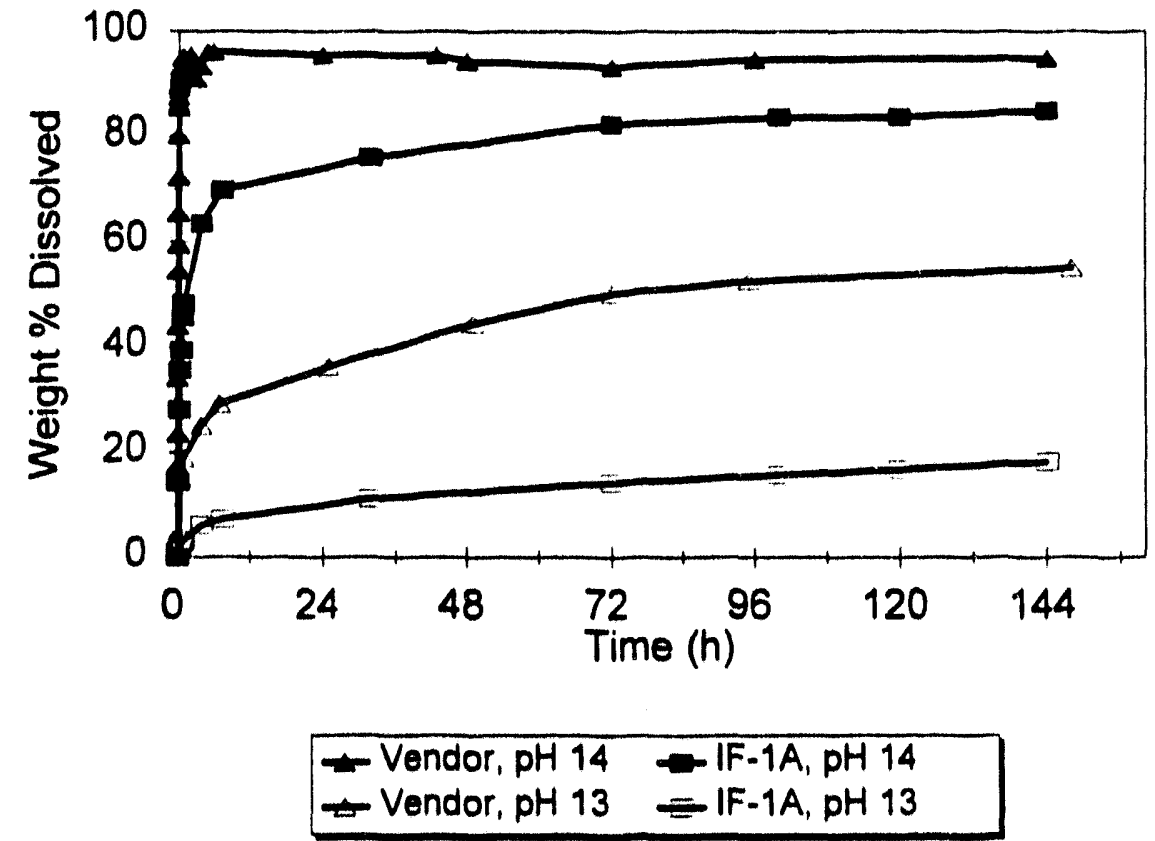

Figure 3.7. Temperature Dependence of IF-1A Dissolution at pH $13,1 \mathrm{M} \mathrm{Na}^{+}$ 


\subsection{Hydrolysis Studies}

Hydrolysis screening studies were conducted at two widely different potential tank conditions. In one experiment, hydrolysis in $4 \mathrm{M} \mathrm{NaOH}$ at $90^{\circ} \mathrm{C}$ was investigated to simulate conditions when highly caustic decladding waste or evaporator bottoms were added to bedded ferrocyanides. The other experiment, at $\mathrm{pH} 10$ and $60^{\circ} \mathrm{C}$, investigated conditions in areas of the tanks that may not have been exposed to high pH waste.

Dried IF-1A (5.725 g) was contacted with $4 \mathrm{M} \mathrm{NaOH}(100 \mathrm{~mL})$ for 3 weeks at $90^{\circ} \mathrm{C}$ in a gamma field of $1.43 \times 10^{3} \mathrm{Rad} / \mathrm{h}$. The reaction solution was sparged with argon before sealing. An identical reaction mixture was heated to $90^{\circ} \mathrm{C}$ outside the pit as a control. Neither solution was stirred mechanically. The final reaction solutions were analyzed for ammonia using an ammoniaselective electrode (Table 3.3). The ammonia concentration in the gamma-irradiated solution $(0.0938 M)$ was 8.6 times that found in the control $(0.0109 M)$. Preliminary infrared analytical results also indicatr, a higher ammonia concentration in the gas phase over the gamma-irradiated solution. The theoretical ammonia concentration (all cyanide ions converted to ammonia by hydrolysis and all ammonia being in solution) is $0.225 \mathrm{M}$, indicating a percent conversion of at least $42 \%$ in the gamma field and $4.8 \%$ in the control, based only on the solution concentrations. These results suggest that gamma radiation promotes hydrolysis, possibly by facilitating the dissociation of cyanide ions from the iron coordination center.

Table 3.3 summarizes other analytical results from the $4 M \mathrm{NaOH}$ experiments. The formate concentration (IC) in the control solution (outside the gamma field) is in excellent agreement with the measured solution concentration of ammonia. However, the one-to-one correlation is not observed in the gamma-irradiated solution, with a formate concentration about 8 times lower than the ammonia concentration. Gamma radiation degrades formate to $\mathrm{CO}_{3}^{-}$radical anion (Goldstein et al. 1988), which should form carbonate in basic solution. This is consistent with infrared spectra of the insoluble solids, which showed more carbonate in the gamma solids than in the control. Gamma solids were red, suggesting the presence of iron oxides. X-ray diffraction also suggested that a small amount of crystalline $\mathrm{Fe}_{2} \mathrm{O}_{3}$ was present, but its presence is uncertain because XRD peaks for this phase were very small and difficult to separate from ferrocyanide and nickel hydroxide peaks. Also, Robuck and Luthy reported $\mathrm{Fe}_{3} \mathrm{O}_{4}$ (Robuck and Luthy 1989). Infrared was inconclusive regarding

Table 3.3. Solution Analytical Data for Reaction Products from Hydrolysis of In-Farm-1A, Rev. 4

\begin{tabular}{|c|c|c|c|c|}
\hline \multirow[b]{2}{*}{ Analyte } & \multicolumn{2}{|c|}{$4 M \mathrm{NaOH}, 90^{\circ} \mathrm{C}$} & \multicolumn{2}{|c|}{$\mathrm{pH} 10,60^{\circ} \mathrm{C}$} \\
\hline & Control & Gamma & Control & Gamma \\
\hline $\mathrm{NH}_{3}$ & $0.0109 M$ & $0.0938 M$ & $2.88 \times 10^{-4} M$ & $1.80 \times 10^{-3} M$ \\
\hline $\mathrm{HCO}_{2}^{-}$ & $0.015 M$ & $0.015 M$ & $0.0039 M$ & $0.0021 M$ \\
\hline $\mathrm{NO}_{3}{ }^{-}$ & $0.288 M$ & $0.146 \mathrm{M}$ & $1.063 M$ & $0.937 M$ \\
\hline $\mathrm{NO}_{2}^{-}$ & $0.090 \mathrm{M}$ & $0.252 M$ & $0.102 M$ & $0.216 M$ \\
\hline $\mathrm{Fe}$ & $1,675 \mathrm{ppm}$ & 890 ppm & $0.57 \pm 0.68 \mathrm{ppm}$ & $4.34 \pm 0.41 \mathrm{ppm}$ \\
\hline$\overline{C s}$ & $5.1 \mathrm{ppm}$ & $8.7 \mathrm{ppm}$ & $8.0 \pm 1.8 \mathrm{ppm}$ & $0.52 \pm 0.56 \mathrm{ppm}$ \\
\hline
\end{tabular}


the presence of $\mathrm{Fe}_{2} \mathrm{O}_{3}$ or other iron oxide phases. The concentration of soluble iron was found (by AA) to be 1675 and $890 \mathrm{ppm}$ for the control and gamma solutions, respectively. Infrared is being used 'o determine what fraction of this iron is in the form of ferrocyanide. The lower iron concentration in the gamma sample is consistent with more extensive hydrolysis, which should result in the precipitation of iron oxides. A small amount of cesium was detected in solution; however, the concentrations are close to the detection limit in the high sodium ion media and should be interpreted with caution. The concentrations reported in Table 3.3 correspond to $2 \%$ to $4 \%$ cesium dissolution.

A similar experiment was conducted at $\mathrm{pH} 10$ and $60^{\circ} \mathrm{C}$ for 4 weeks at the same dose rate. The $\mathrm{Na}^{+}$concentration was adjusted to $1 M$ with $\mathrm{NaNO}_{3}$. Compared with the $4 M \mathrm{NaOH}$ experiment, 2 orders of magnitude less ammonia (just above the detection limit of the ammonia probe) was observed for both the control and irradiated solutions. The measured formate concentrations were also much lower, and also approach the detertion limit. The control supernate was colorless and contained no soluble iron, indicating no dissolution at $\mathrm{pH} 10$. The irradiated solution showed a trace of soluble iron corresponding to $0.2 \%$ dissolution. Little or no cesium dissolution occurred.

Analyses for $\mathrm{NO}_{3}^{-}$and $\mathrm{NO}_{2}^{-}$in $4 \mathrm{M} \mathrm{NaOH}$ and $\mathrm{pH} 10$ solutions are consistent with the amounts initially added. The $\mathrm{NO}_{3}{ }^{-}$and $\mathrm{NO}_{2}{ }^{-}$concentrations in the $4 \mathrm{M} \mathrm{NaOH}$ control experiment are essentially those arising from dissolution of the IF-1A material, calculated to be $0.301 \mathrm{M}$ and $0.100 \mathrm{M}$, respectively. The sum of the concentrations, $0.4 \mathrm{M}$, is maintained in the gamma solutions, although a net conversion of $\mathrm{NO}_{3}{ }^{+}$to $\mathrm{NO}_{2}^{-}$is observed. Similarly, the concentrations of these anions in the pH 10 control solution are the same as those calculated to have been added, and the sum (1.165 M) remains about constant on gamma irradiation. 


\subsection{Conclusions}

Vendor-prepared $\mathrm{Na}_{2} \mathrm{NiFe}(\mathrm{CN})_{6}$ dissolves in aqueous base to give primarily insoluble $\mathrm{Ni}(\mathrm{OH})_{2}$ and soluble $\mathrm{Na}_{4} \mathrm{Fe}(\mathrm{CN})_{6}$. The rate of dissolution of $\mathrm{Na}_{2} \mathrm{NiFe}(\mathrm{CN})_{6}$ in aqueous base increases with increasing pH. At pH 14, 95\% dissolution is observed after $0.5 \mathrm{~h}$. Addition of sodium ion in the form of $\mathrm{Na}_{2} \mathrm{SO}_{4}$ or $\mathrm{NaNO}_{3}$ suppresses dissolution at $\mathrm{pH} 13$. However, $1 \mathrm{M} \mathrm{Na}^{+}$in the form of $\mathrm{Na}_{2} \mathrm{CO}_{3}, \mathrm{Na}_{3} \mathrm{PO}_{4}$, or SST simulant salts (mixed sodium salts of phosphate, carbonate, nitrate, nitrite, sulfate, and hydroxide) results in an enhancement of the rate of solubilization. At pH 14 these effects are not seen, dissolution being rapid even in the presence of $4 M$ sodium ion. The rate of dissolution is influenced most by base concentration.

Dissolution of IF-1A, containing $4.51 \times 10^{-2}$ moles $\mathrm{Cs} /$ moles ferrocyanide, takes place more slowly than the vendor material under identical conditions at both $\mathrm{pH} 13$ and $\mathrm{pH} 14$. A material containing a $\mathrm{Cs}_{2} \mathrm{NiFe}(\mathrm{CN})_{6}$ phase $(2.3$ moles $\mathrm{Cs} /$ moles ferrocyanide) was found to be insoluble in up to $4 M \mathrm{NaOH}$ after stirring for $144 \mathrm{~h}$. The inhibition of IF-1A dissolution may be due to concentration of an insoluble (or less soluble) $\mathrm{Cs}_{2} \mathrm{NiFe}(\mathrm{CN})_{6}$ or $\mathrm{NaCsNiFe}(\mathrm{CN})_{6}$ phase at the particle surface as $\mathrm{Na}_{2} \mathrm{NiFe}(\mathrm{CN})_{6}$ dissolves.

Studies of the hydrolysis of IF-1A in $4 \mathrm{M} \mathrm{NaOH}$ indicate that gamma accelerates the hydrolysis reaction. After 3 weeks at $90^{\circ} \mathrm{C}$, gamma-irradiated IF-1A was at least $42 \%$ degraded to ammonia. An identical control experiment not receiving gamma radiation showed about 8.6 times less hydrolysis. Little dissolution and hydrolysis occurs in $\mathrm{pH} 10$ solution at $60^{\circ} \mathrm{C}$. 


\subsection{Future Work}

The kinetics of hydrolysis of ferrocyanide materials is an area for continued research in FY 1994. A better understanding of hydrolysis rates and determination of the activation energy for hydrolysis under tank conditions is needed in order to determine the extent of ferrocyanide destruction that may have occurred during decades of storage. The effect of limiting the $\mathrm{NaOH}$ to below stoichiometric amounts will also be evaluated. Experiments investigating bench top and gamma pit hydrolysis in the presence of a decladding waste simulant should be conducted. Aging kinetic studies coupled with microconvective modeling studies now being conducted will indicate the plausibility of the aging mechanism.

Dissolution of the IF-1A flowsheet material should be investigated under conditions of constant pH. As conducted now, the $\mathrm{pH}$ decreases as the ferrocyanide dissolves, preventing determination of the rate of dissolution. Maintaining a constant $\mathrm{pH}$ will remove this complicating factor. Because the reaction is heterogeneous, other complicating factors will remain, such as particle size and stirring rate variations. These effects can be minimized to obtain global dissolution rates. 


\subsection{References}

Anderson, J. D. 1990. A History of the 100 Area Tank Farms. WHC-MR-0132, Westinghouse Hanford Company, Richland, Washington.

Babad, H., D. M. Camaioni, M. A. Lilga, W. D. Samuels, and D. M. Strachan. 1993. Tank Waste Chemistry - A New Understandine of Waste Aging. WHC-SA-1694-FP, Westinghouse Hanford Company, Richland, Washington.

Borsheim, G. L., and B. C. Simpson. 1991. An Assessment of the Inventories of the Ferrecyanide Watchlist Tanks. WHC-SD-WM-ER-133 Rev. 0, Westinghouse Hanford Company, Richland, Washington.

Burger, L. L. 1984. Complexant Stability Investioation. Task L-Ferrocyanide Solids. PNL-5441, Pacific Northwest Laboratory, Richland, Washington.

Burger, L. L., and R. D. Scheele. 1988. Interim Report - Cyanide Safety Studies. PNL-7175, Pacific Northwest Laboratory, Richland, Washington.

Burger, L. L., and R. D. Scheele. 1991. The Reactivity of Cesium Nickel Ferrocyanide Towards Nitrate and Nitrite Salts - A Status Report. PNL-7550, Pacific Northwest Laboratory, Richland, Washington.

Campbell, D. O., D. D. Le, and T. A. Dillow. 1990. "Low-Lovel Liquid Waste Decontamination by Ion Exchange." Warte Manarement '90, ed. R. G. Post. 2:389-398.

Goldstein, S., G. Czapski, H. Cohen, and D. Meyerstein. 1988. "Formation and Decomposition of Iron-Carbon $\sigma$-Bonds in the Reaction of Iron(III)-Poly(amino carboxylate) Complexes with $\mathrm{CO}_{2}^{-}$Free Radicals. A Pulse Radiolysis Study." L_Am. Chem_Soc. 110(12):3903-3907.

Jeppson, D. W., and J. J. Wong. 1993. Eerrocyanide Waste Simulant Characterization. WHC-EP-0631, Westinghouse Hanford Company, Richland, Washington.

Lilga, M. A., M. R. Lumetta, W. F. Riomath, R. A. Romine, and G. F. Schiefelbein. 1992. Eerrocyanide Safety Project. Subtack 3.4. Aqine Studies FY 1992 Annual Report. PNL-8387, Pacific Northwest Laboratory, Richland, Washington.

Loos-Neskovic, C., M. Fedoroff, E. Garnier, and P. Gravereau. 1984. "Zinc and Nickel Ferrocyanides: Proparation, Composition and Structure." Talanta 31(12):1133-1147.

Loos-Neskovic, C., and M. Fedoroff. 1989. "Fixation Mechanisms of Cesium on Nickel and Zinc Ferrocyanides." Solvent Extraction and lon Exchange 7(1):131-158.

Loos-Neskovic, C., M. Fedoroff, and E. Garnier. 1989. "Preparation, Composition and Structure of Some Nickel and Zinc Ferrocyanides: Experimental Results." Talants 36(7):749-759. 
McGrail, E. P., D. S. Trent, G. Terrones, J. D. Hudson, and T. E. Michener. 1993.

Computational Analysis of Fluid Flow and Zonal Deposition in Ferrocyanide Single-Shell Tanks.

PNL-8876, Pacific Northwest Laboratory, Richland, Washington.

Peach, J. D. 1990. "Consequences of Explosion of Hanford's Single-Shell Tanks Are

Underestimated." Letter B-241479 dated October 1990 to M. Synar, GAO/RCED-91-34, General Accounting Office, Washington, D.C.

Robuck, S. J., and R. G. Luthy. 1989. "Destruction of Iron-Complexed Cyanide by Alkaline Hydrolysis." Wat. Sci. Tech, 21:547-558.

Scheele, R. D., L. L. Burger, J. M. Tingey, S. A. Bryan, G. L. Borsheim, B. C. Simpson, R. J. Cash, and H. H. Cady. 1991. "Ferrocyanide-Containing Waste Tanks: Ferrocyanide Chemistry and Reactivity." PNL-SA-19924, presented at Environmental Restoration 1991, Pasco, Washington.

U.S. Department of Energy (DOE). 1987. Einal Environmental Impact Statement. Disposal of Hanford Defense Hiah-Level. Transuranic, and Tank Wastes. DOE-EIS-0113, Washington, D.C.

U.S. Department of Energy (DOE). 1990. "DOE to Develop Supplemental Environmental Impact Statement for Hanford." Press Release, October 9, 1990, Washington, D.C. 


\section{Distribution}

No. of

Copies

\section{OFFSITE}

12 DOE Office of Scientific and Technical Information

\section{John C. Tseng}

U.S. Department of Energy

EM-35, Trevion II

Washington, D.C. 20585

Thomas C. Temple

U.S. Department of Energy

Savannah River Operations Office

P.O. Box A

Aiken, SC 29808

Charles S. Abrams

1987 Virginia

Idaho Falls, ID 83404

David O. Campbell

102 Windham Road

Oak Ridge, TN 37830

Fred N. Carlson

6965 North 5th West

Idaho Falls, ID 83401

Donald T. Oakley

409 12th Street SW, Suite 310

Washington, D.C. $20024-2188$

Arlin K. Postma

3640 Ballard Road

Dallis, OR 97338

William R. Prindle

1556 Crestline Drive

Santa Barbara, CA 93105

Alfred Schneider

5005 Hidden Branches Drive

Dunwoody, GA 30338
No. of

Copies

George E. Schmauch

Air Products \& Chemicals

7201 Hamilton Blvd.

Allentown, PA 18195-1501

James A. Gieseke

Battelle Columbus Division

505 King Avenue

Columbus, OH 43201-2693

Kamal K. Bandyopadhyay

Brookhaven National Laboratory

Upton, NY 11973

Gary Powers

Design Science, Inc.

163 Witherow Road

Sewickley, PA 15143

Hans K. Fauske

Fauske and Associates, Inc.

16W070 W. 83rd St.

Burr Ridge, IL 60521

Gregory R. Choppin

Florida State University

Department of Chemistry B-164

Tallahassee, FL 32306

Melvin W. First

Harvard University

295 Upland Avenue

Newton Highlands, MA 02161

Chester Grelecki

Hazards Research Corporation

200 Valloy Road, Sulte 301

Mt. Arlington, NJ 07856

Billy C. Hudson

Lawrence Livermore National

Laboratory

P.O. Box 808, L-221

Livermore, CA 94550

Distr. 1 
No. of

Copies

Steve F. Agnew

Los Alamos National Laboratory

P.O. Box 1663

Los Alamos, NM 87545

Steve Eisenhawer

Los Alamos National Laboratory

P.O. Box 1663

Los Alamos, NM 87545

Thomas E. Larson

Los Alamos National Laboratory

P.O. Box 1663

Los Alamos, NM 87545

L. Harold Sullivan

Los Alamos National Laboratory

P.O. Box 1663

Los Alamos, NM 87545

Mujid S. Kazimi

MIT/Dept of Nuclear Eng.

77 Massachusetts Avenue

Room 24-102

Cambridge, MA 02139

Louis Kovach

NUCON

P.O. Box 29151

Columbus, $\mathrm{OH} 43229$

Emory D. Collins

Oak Ridge National Laboratory

P.O. Box 2008

7930, MS-6385

Oak Ridge, TN 37831-6385

Charles W. Forsberg

Oak Ridge National Laboratory

P.O. Box 2008

MS-6495

Oak Ridge, TN 37831-6495
No. of

Copies

Thomas S. Kress

P.O. Box 2009

9108, MS-8088

Oak Ridge, TN 37831-8088

Andrew S. Veletsos

Rice University

5211 Paisley

Houston, TX 77096

Scott E. Slezak

Sandia National Laboratory

P.O. Box 5800

Albuquerque, NM 87185

3 Ray S. Daniels

Science Applications International

Corporation

12850 Middlebrook Road

Trevion I, Suite 300

Germantown, MD 20874

Joseph S. Byrd

University of South Carolina

Department of Electrical and

Computer Engineering

Swearingen Engineering Center

Columbia, SC 29208

Bruce R. Kowalski

University of Washirgton

Center for Process Analytical Chemistry

Chemistry Department BG-10

Seattle, WA 98195

Frank L. Parker

Vanderbilt University

P.O. Box 1596, Station B

Nashville, TN 37235 
No. of

Copies

ONSITE

9 DOE Richland Operations Office

R. F. Christensen (4)

A4-02

R. E. Gerton

A4-02

A. G. Krasopoulos

Public Reading Room

A5-55

A1-65

RL Docket File (2)

H5-36

46 Westinghouse Hanford Company

H. Babad

R2-78

J. B. Billetdeaux

D. C. Board

R2-08

G. L. Borsheim

J. G. Burk

S1-57

R2-11

B3-25

R. J. Cash (2)

M. D. Crippen

R2-78

L5-31

G. M. Christensen

H4-21

C. DeFigh-Price

D. R. Dickinson

G. T. Dukelow

J. C. Fulton

K. A. Gasper

J. M. Grigsby

H. D. Harmon

J. M. Held

M. N. Islam

D. W. Jeppson

D. R. Johnson

N. W. Kirch

C. A. Kuhlman

M. Kummerer

J. D. McCormack

L5-31

R2-78

R2-31

R2-08

H4-62

R2-52

R3-09

R3-08

L5-31

R2-08

R2-11

B3-30

H4-62

L5-31
No. of

Copies

J. M. McLaren H0-34

J. E. Meacham R2-78

N. J. Milliken H4-63

S. R. Moreno B3-06

A. F. Noonan R2-12

J. G. Propson R2-18

$\begin{array}{ll}\text { I. E. Reep R2-08 } & \text { R. }\end{array}$

F. R. Reich L5-63

D. A. Reynolds R2-11

N. L. Simon R2-78

B. C. Simpson R2-12

H. Toffer H0-38

W. D. Winkelman L5-55

D. D. Wodrich R2-85

Document Processing and

Distribution (2) L8-15

Central Files L8-04

EDMC H6-08

Information Release

Administration (3) R1-08

TFIC R1-20

28 Pacific Northwest Laboratory

R. T. Allemann K7-15

S. A. Bryan P7-25

R. T. Hallen P8-38

B. M. Johnson K1-78

M. A. Lilga (10) P8-38

M. R. Lumetta P8-38

B. P. McGrail K2-38

R. D. Scheele P7-25

G. F. Schiefelbein (5) P8-38

Publishing Coordination

Technical Report Files (5) K1-11

Distr.3 


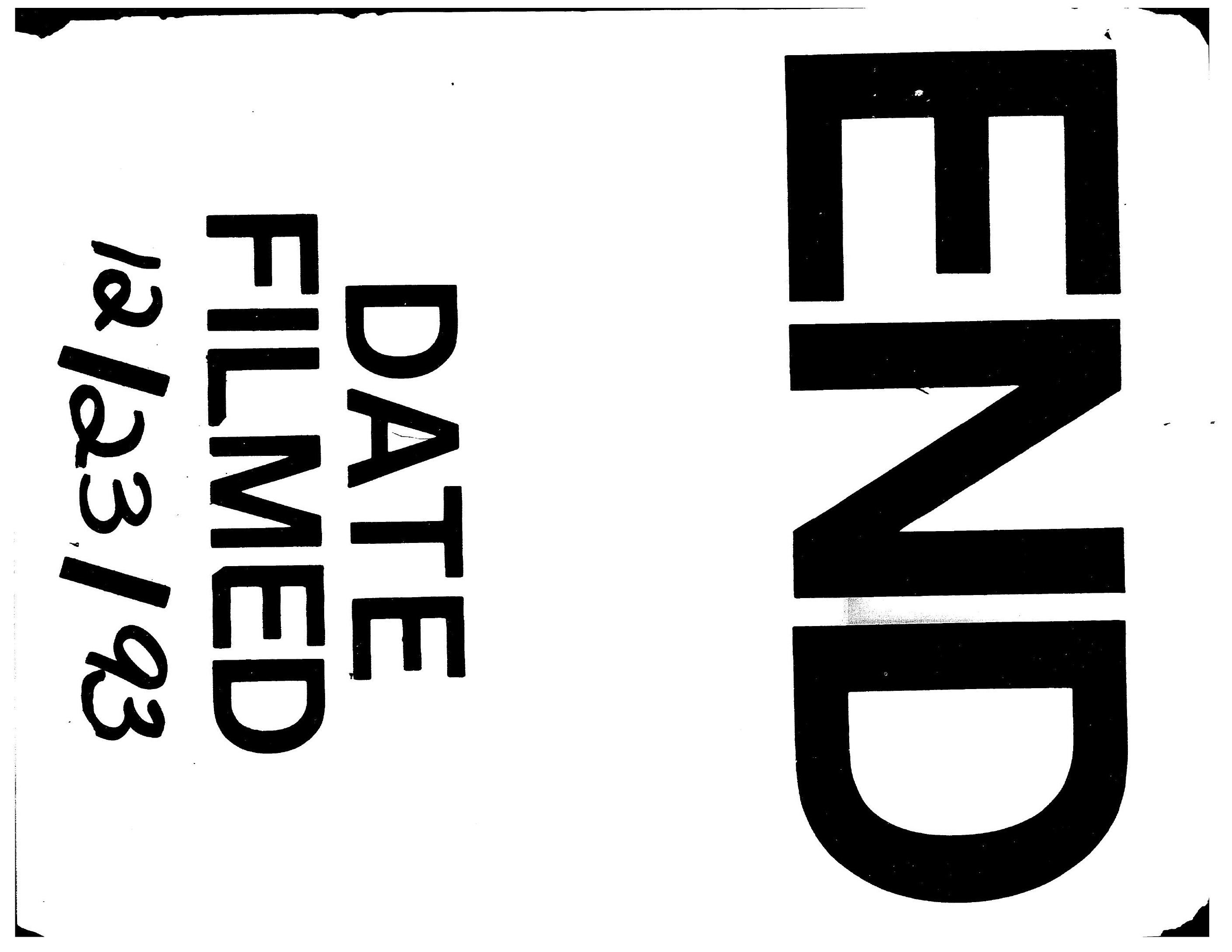




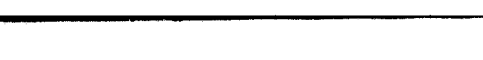 \\ $\longrightarrow$}
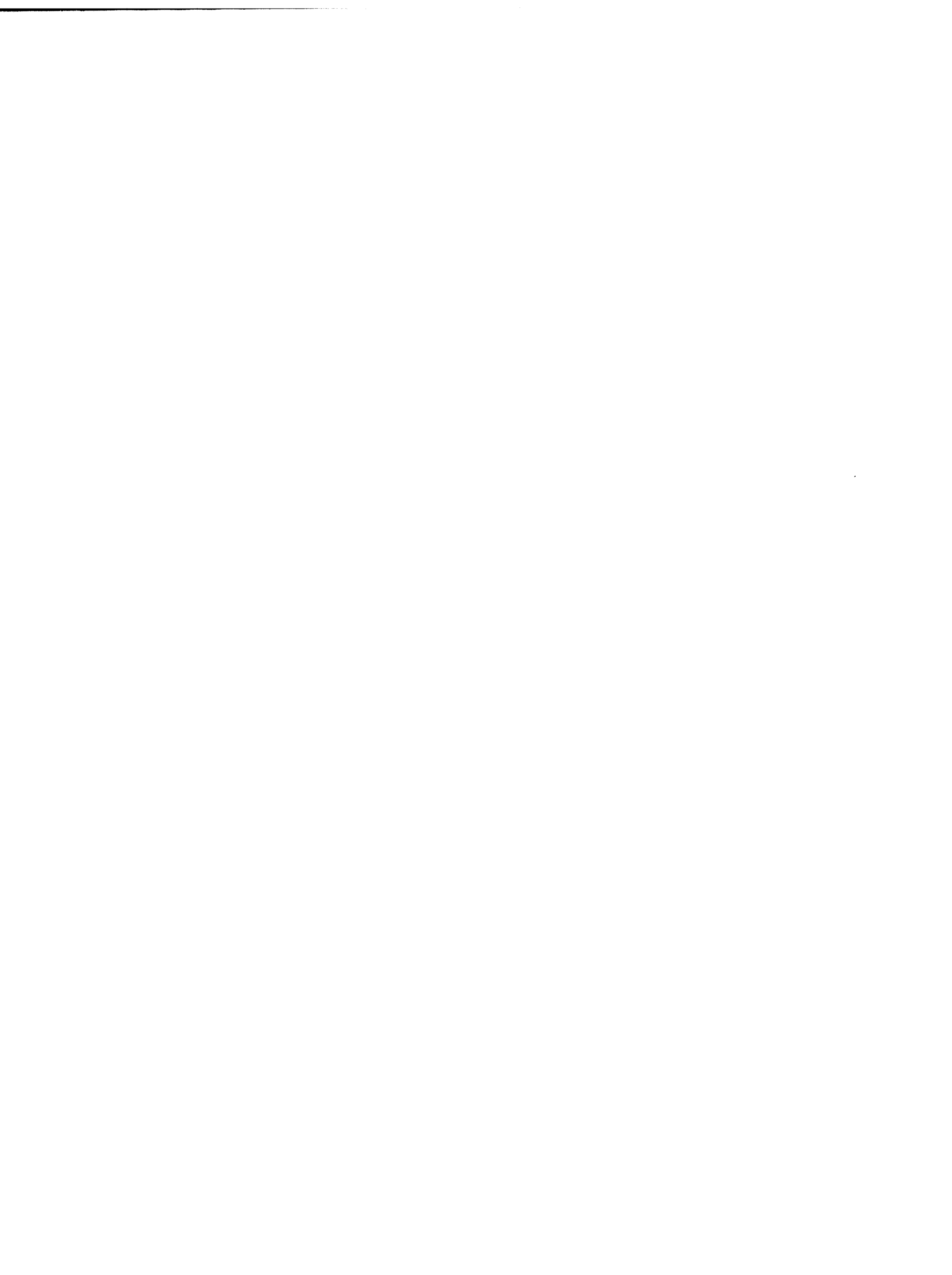

$$
+
$$

